Journal of Epidemiology and Public Health (2017), 2(2): 154-163

https://doi.org/10.26911/jepublichealth.2017.02.02.06

\title{
Knowledge, Attitude, Sexual Behavior, Family Support, and Their Associations with HIV/AIDS Status in Housewives
}

\author{
Budi Laksana1,2), Argyo Demartoto3), Dono Indarto4) \\ 1)Diploma III Program in Midwifery Muhammadiyah, Madiun, East Java \\ ${ }^{2)}$ Masters Program in Public Health, Universitas Sebelas Maret \\ 3)Faculty of Social and Political Sciences, Universitas Sebelas Maret \\ 4)Department of Physiology, Faculty of Medicine,Universitas Sebelas Maret
}

\begin{abstract}
Background: Approximately 36.7 million people in the world were infected by HIV and 2.1 million new cases occured in 2015. A total of 191,073 HIV cases were reported in Indonesia in 2016, including 77,940 AIDS cases, and 13,247 deaths. Housewives ranked highest among HIV/AIDS patients in Indonesia. This study aimed to investigate knowledge, attitude, sexual behavior, family support, and their associations with HIV status in housewives using PRECEDE PROCEED model.

Subjects and Method: This was an analytic observational study with cross-sectional design. The study was conducted at Toroh community health center, Grobogan, Central Java, in July, 2017. A total sample of 129 housewives were selected for this study using exhaustive sampling technique. The dependent variable was HIV status. The independent variables were knowledge, attitude, sexual behavior, and family support. The data was measured by a set of questionnaire and analyzed using path analysis.

Results: HIV status was directly and positively associated with risky sexual behavior $(b=4.48$; $95 \% \mathrm{CI}=2.30$ to $6.65 ; \mathrm{p}<0.001)$. Risky sexual behavior was associated with attitude $(\mathrm{b}=-1.27 ; 95 \%$ $\mathrm{CI}=-0.03$ to $-2.51 ; \mathrm{p}<0.045)$ and family support $(\mathrm{b}=-1.86 ; 95 \% \mathrm{CI}=-0.69$ to $-3.03 ; \mathrm{p}<0.002)$. Attitude was associated with knowledge $(\mathrm{b}=2.06 ; 95 \% \mathrm{CI}=0.86$ to $3.25 ; \mathrm{p}<0.001)$.

Conclusion: HIV status is directly and positively associated with risky sexual behavior. HIV status is indirectly associated with attitude, knowledge, and family support.
\end{abstract}

Keywords: HIV, AIDS, risky sexual behavior, housewives, PRECEDE PROCEED model

\section{Correspondence:}

Budi Laksana. Diploma III Program in Midwifery Muhammadiyah, Madiun, East Java. Email: lakortikosteroid@gmail.com. Mobile: +628565561200o.

\section{BACKGROUND}

According to WHO (2013), HIV (Human Immunodeficiency Virus) is a type of virus that works by reducing the immune system, so that people affected by this virus become susceptible to various infections or also easily affected by tumors. AIDS (Aquired Immunodeficiency Syndrome) is a collection of symptoms that arise due to reduced self-defense or immune system caused by the entry of the HIV virus in a person's body (Spiritia, 2009).

HIV/AIDS is considered as a serious threat globally, HIV/AIDS does not only occur in developing countries but also occurs with a high incidence in developing countries. The number of people living with HIV/AIDS worldwide has reached 36.7 million people and 2.1 million new people were infected with HIV in 2015 (WHO, 2015). HIV cases in Asia are generally found in Injecting Drug Users (IDUs) of heterosexual and homosexual sex workers and regular sex partners (KPAN, 2010). HIV cases in Southeast Asia in the last 15 years have increased from 2.9 million to 3.5 million (WHO, 2016). Especially in Indonesia, 191,073 cases of cumulative HIV were 
recorded until March 31, 2016, and AIDS cases were 77,940 while 13,247 patients died from AIDS infection (Spiritia, 2016).

Cumulatively the number of HIV cases in Central Java as of March 31, 2016 was recorded at 13,547 and AIDS cases were 5 ,049 with a mortality rate of $28.6 \%$. Data from the Ministry of Health of the Republic of Indonesia states that cumulatively up to December 2015 the number of housewives is very high amounting to 9.096 people with HIV/AIDS. While the second place is 8,287 employees, while the unknown profession reaches 21,434 people (Spiritia, 2016).

A preliminary study conducted at the Grobogan District Health Office showed that as of November 2016 the number of HIV/AIDS cases was 858 with details of 428 men and 430 women. The total deaths were 111 people.

According to Green and Kreuter (2005), health behavior is influenced by individual and environmental factors with the PRECEDE PROCEED behavior change model. Behavior is influenced by 3 main factors, namely: predisposing factors (predisposing factors), enabling factors (reinforcing factors) and reinforcing factors (reinforcing factors) which are part of the PRECEDE model. One of the causes that play a role in increasing the spread of HIV / AIDS is the pattern of sexual relations, attitudes, and knowledge. Factors of sexual relations patterns become one of the predisposing factors in the theory which will be discussed using PRECEDE PROCEED that will show the predisposing factors that influence the increase in HIV/AIDS cases, because sexual intercourse patterns of multiple sex partners are considered to be the rapid predictors of the spread of HIV/AIDS. Knowledge is also an ability to form thought patterns that can describe objects correctly and represent them in an action on an object (Kusrini, 2009).

Based on the description above, the author is interested in examining the influence of knowledge, attitudes, family support, sexual relations patterns using the PRECEDE-PROCEED theory with path analysis, to determine the direct or indirect influence on HIV/AIDS status on housewives.

\section{SUBJECTS AND METHOD}

\section{Study Design}

This study was an observational analytic study, with a cross sectional design approach. The implementation began in July in the work area of the Toroh Health Center, Grobogan Regency, East Java. As for the consideration, the authors chose the location of the study in Grobogan Regency because until November 2016 there was an increase in HIV cases in women, especially housewives. The data collection was done by filling out questionnaires by the Study Subjects.

\section{Population and Sampling}

The population of this study was all housewives in the work area of the Toroh Community Health Center in Grobogan Regency who had conducted VCT in 2016 amounting 528.

The Study Subjects of this study were housewives who lived in the work area of Toroh Health Center, Grobogan Regency who had conducted VCT examinations and were willing to be the subjects of the study. Inclusion criteria included, living in the work area of the Toroh Health Center, VCT conducted in January to June 2017. The criteria exclusion include Injecting Narcotics Users, MRS (Entering the Hospital), Moving addresses or unable to be contacted. The sample is part or representative of the population studied. This study uses total sampling, which is taking all Study Subjects 
Journal of Epidemiology and Public Health (2017), 2(2): 154-163

https://doi.org/10.26911/jepublichealth.2017.02.02.06

as samples. The sample amounted to 129 housewives.

\section{Study Variables}

Exogenous variables, namely education, knowledge, attitudes, family support, and perceptions of husband's health, and endogenous variables of sexual relations patterns and status of HIV/AIDS on housewives both affect directly or indirectly.

\section{Operational Definition of Variables} HIV/AIDS status was the condition of a person related to the status of contracting HIV/AIDS.

Pattern of sexual relations was the number of partners in sexual intercourse, grouped into two categories namely, single sex partner and multiple sex.

Family support was the support provided by the family including attitudes and behaviors that manifest in action and acceptance of family members.

Attitude was a view or feeling accompanied by a tendency to carry out an action in accordance with the things that are believed to be HIV/AIDS.

Knowledge was the result of sensing someone against an object through their senses (eyes, ears, nose, etc.).

\section{Study Instruments}

Data collection in this study using primary data obtained from the results of filling in a guided questionnaire (structure interview) with all housewives with positive and negative HIV/AIDS. This data collection was carried out by authors and assisted by officers from the Grobogan District Health Office and health center who had the same perception in conducting questionnaire filling guidelines.

\section{Data Analysis}

The analysis used in this study was path analysis. Path analysis is an analytical technique that is used to determine the effect of an exogenous variable on endogenous variables that affect both directly and indirec- tly. The magnitude of the influence of the independent variable (exogenous) on the dependent variable (endogenous) can be seen from the value of the path coefficient, the greater the path coefficient, the greater the influence given by the variable.

The steps in analyzing the data using path analysis include model specifications, model identification, parameter estimation and model specification.

\section{RESULTS}

\section{Sample Characteristics}

The study was conducted on 129 housewives in Grobogan Regency. The data collection was carried out in July 2017.

\section{Bivariate Analysis}

Bivariate analysis explains the effect of one dependent variable on one dependent variable. The independent variables of this study were sexual relations patterns, attitudes, perceptions about husband's health, education, knowledge, and family support, on the dependent variable namely HIV/ AIDS status. The method used is logistic regression with a confidence level of $95 \%$ $(\mathrm{p}=0.05)$.

Table 2 shows that housewives with less knowledge are 0.06 times more likely to contract HIV / AIDS than IRTs with low knowledge. The Chi-Square test results showed that there was an effect of the knowledge on HIV / AIDS status on the housewives and was statistically significant (OR = 0.06; $\mathrm{p}<0.001$ ).

Housewives who have bad attitude are likely to be 0.014 times to contract HIV / AIDS than housewives who have good attitude. The results of the Chi-Square test showed that there was an influence of attitude of housewives with HIV / AIDS status and was statistically significant $(\mathrm{OR}=0.014 ; \mathrm{p}$ $<0.001$ ).

Housewives who have poor family support have a 0.018 times greater likeli- 
hood of being HIV/AIDS positive compared to those who have good family support. The Chi Square test results showed that there was an effect of family support on HIV/ AIDS status on housewives and was statistically significant $(\mathrm{OR}=0.018 ; \mathrm{p}<0.001)$.

Housewives who have sexual intercourse patterns of multiple sex partners have a possibility of 0.011 times greater status of positive HIV/AIDS than housewives who do not have a single sex partner sexual relationship pattern. Chi Square test results showed that there was an effect of sexual relations patterns on HIV / AIDS status and was statistically significant $(\mathrm{OR}=0.011 ; \mathrm{p}$ $<0.001)$.

Table 1. The characteristics of housewives in the work area of Toroh 1 Health Center, Grobogan Regency

\begin{tabular}{llcc}
\hline Characteristics & \multicolumn{1}{c}{ Category } & Frequency (n) & Percentage (\%) \\
\hline Age (years) & $<20$ & 13 & 10.1 \\
& $20-35$ & 93 & 72.1 \\
& $>35$ & 23 & 17.8 \\
Education & $<$ SHS & 35 & 27.1 \\
\multirow{2}{*}{ Family Income } & $\geq$ SHS & 94 & 72.9 \\
& $<$ Minimum wage & 87 & 67.4 \\
& $\geq$ Minimum wage & 42 & 32.6 \\
\hline
\end{tabular}

Table 2. The results of bivariate analysis of knowledge, attitudes, family support, and sexual relations patterns on HIV / AIDS status on housewives in the work area of Toroh Health Center, Grobogan Regency

\begin{tabular}{|c|c|c|c|c|c|c|c|c|c|}
\hline \multirow{3}{*}{ Variable } & \multicolumn{4}{|c|}{ HIV/AIDS Status } & \multirow{2}{*}{\multicolumn{2}{|c|}{ Total }} & \multirow{3}{*}{ OR } & \multirow{3}{*}{$95 \%$ CI } & \multirow{3}{*}{$\mathbf{p}$} \\
\hline & \multicolumn{2}{|c|}{ Negative } & \multicolumn{2}{|c|}{ Positive } & & & & & \\
\hline & $\mathbf{n}$ & $\%$ & $\mathbf{n}$ & $\%$ & $\mathbf{n}$ & $\%$ & & & \\
\hline \multicolumn{10}{|l|}{ Knowledge } \\
\hline Poor & 9 & 64.3 & 5 & 35.7 & 14 & 10.9 & \multirow[t]{2}{*}{0.06} & \multirow{3}{*}{0.01 to 0.28} & \multirow[t]{3}{*}{$<0.001$} \\
\hline Good & 111 & 96.5 & 4 & 3.5 & 115 & 89.1 & & & \\
\hline \multicolumn{8}{|l|}{ Attitude } & & \\
\hline Poor & 12 & 60 & 8 & 40 & 20 & $15 \cdot 5$ & \multirow[t]{2}{*}{0.01} & \multirow{3}{*}{$<0.01$ to 0.12} & \multirow[t]{2}{*}{$<0.001$} \\
\hline Good & 108 & 99.1 & 1 & 0.9 & 109 & 84.5 & & & \\
\hline \multicolumn{9}{|l|}{ Family Support } & \\
\hline Poor & 15 & 65.5 & 8 & 34.8 & 23 & 17.8 & \multirow[t]{2}{*}{0.02} & \multirow{2}{*}{$<0.01$ to 0.15} & \multirow[t]{2}{*}{$<0.001$} \\
\hline Good & 105 & 99.1 & 1 & 0.9 & 106 & 81.2 & & & \\
\hline \multicolumn{10}{|l|}{$\begin{array}{l}\text { Number of Sexual } \\
\text { partner }\end{array}$} \\
\hline Multiple partner sex & 10 & 55.5 & 8 & 44.4 & 18 & 14 & 0.011 & O 01 - 01 & $<0.001$ \\
\hline Single partner sex & 110 & 99.1 & 1 & 0.9 & 111 & 86 & & $0.01-100.10$ & \\
\hline
\end{tabular}

\section{Path analysis}

Path analysis was conducted to find out what variables affected the status of HIV / AIDS on the housewives in the work area of the Toroh health center which consisted of 9 villages in the Toroh sub-district of Grobogan district. a. Model Specification

Model specifications describe the relationship between the variables to be studied. The variables studied were differentiated according to exogenous and endogenous variables. Exogenous variables are variables which in the model are not influenced by other variables, in this study the exogenous variables are knowledge, family support. 
Journal of Epidemiology and Public Health (2017), 2(2): 154-163

https://doi.org/10.26911/jepublichealth.2017.02.02.06

Endogenous variables are variables that are influenced by other variables. Endogenous variables in this study are attitudes, sexual relations patterns and HIV / AIDS status of the housewives. This study has five measured variables (observed variables), namely knowledge, attitudes, family support, sexual relations patterns, and HIV / AIDS status of housewives.

b. Model Identification

Model identification can be done on the number of measured variables, number of endogenous variables, exogenous variables, and parameters that will be estimated by calculating the degree of freedom (df) showing that path analysis can be done.

1) Number of measured variables : 5

2) Exogenous variables :3

3) Endogenous variables : :2

The total of parameter $\quad: 5$

The degree of freedom formula, i.e.:

$\mathrm{df}=$ (the number of measured variables $\mathrm{x}$ (the number of measured variables +1$)$ ) $/ 2$ - (Exogenous variables + Endogenous variables + Number of measured variables ) $\geq 0$ then the path analysis model is called identified. Whereas if the value of $\mathrm{df}>\mathrm{o}$ then the path analysis model is called over identified and if the value of $\mathrm{df}<0$ then it is said that the path analysis model is under identified. The results of the degree of freedom calculation in this study are $(5 \times 15$ $+1)) / 2-(3+2+5)=5$. It is said to be over identified so that path analysis can be done because $\mathrm{df} \geq 0$.

c. Model Suitability

The path analysis model made by author based on the theory was tested according to the best variable relationship model according to a computer program (SPSS Version 22) called the saturation model, which was made based on sample data which was collected by the author. If there was no statistically significant difference between the two models, the model created by the au- thor was a model that matched the data that reflected the reality of the relationship between variables.

\section{d. Parameter Estimation}

The causal relationship of variables was indicated by the regression coefficient (b), both unstandardized or standardized. The regression coefficient with standardization has looked for each standard errors so that the amount of the estimated regression coefficient between one independent variable with another variable can be compared in term of relative importance.

e. Model Respecification

If the model made by the author was not in accordance with the sample data shown by the saturation model and there was also a regression coefficient that has very small value which was close to zero and statistically insignificant, it was necessary to recreate the path analysis model so that the model was in accordance with the sample data. The results of path analysis was conducted by using STATA Version 13.0 shown in Figure 1.

Based on Table 3, it was known that HIV/AIDS status was directly affected by sexual behavior (single sexual partners), and indirectly affected by knowledge, attitudes, and family support.

There was an effect of sexual behavior on HIV/AIDS status among housewives and it was statistically significant. Housewives with single sexual partner of sexual behavior have the logodd of -4.47 units were less likely to expose to positive HIV/AIDS than the housewives with multiple sexual partners $(b=-4.47 ; 95 \% \mathrm{CI}=-6.65$ to -2.30 ; $\mathrm{p}<0.001)$.

There was an effect of housewives' preventive action on HIV/AIDS status through sexual behavior among housewives which was statistically significant. Housewives with good attitudes have the logodd of single partner sexual behavior by 1.3 unit 
higher than the housewives who have bad attitudes $(b=1.26 ; 95 \% \mathrm{CI}=0.02$ to 2.50 ; $\mathrm{p}=0.045)$.

There was an effect of housewives' family support on HIV/AIDS status through sexual behavior which was statistically significant. Housewives with good family support have the logodd of single partner sexual behavior by 1.9 unit higher than the housewives who have lack of family support $(b=1.86 ; 95 \% \mathrm{CI}=0.69$ to $3.03 ; \mathrm{p}=0.002$ ).

There was an effect of knowledge on attitude which was statistically significant. Housewives with good knowledge have the logodd of good attitude by 2.1 units higher than the housewives who have lack of knowledge $(b=2.06$; 95\% $C I=0.86$ to 3.26 ; $\mathrm{p}=0.705)$.

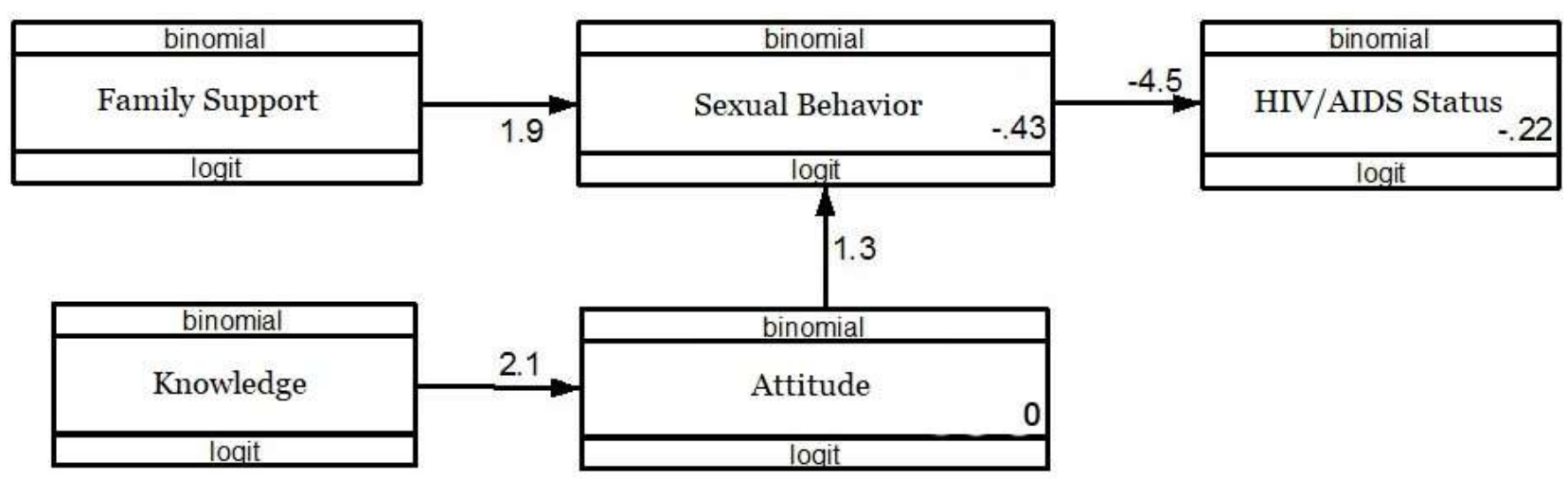

Figure 1. Structural Model with Estimation

Table 3. The Result of Path Analysis

\begin{tabular}{|c|c|c|c|c|c|c|}
\hline \multirow{2}{*}{\multicolumn{2}{|c|}{ Dependent Variables }} & \multirow[b]{2}{*}{$\begin{array}{c}\text { Independent } \\
\text { Variables }\end{array}$} & \multirow{2}{*}{$\begin{array}{c}\text { Path } \\
\text { Coefficient } \\
\text { (b) }\end{array}$} & \multicolumn{2}{|c|}{$95 \% \mathrm{CI}$} & \multirow[b]{2}{*}{$\mathbf{p}$} \\
\hline & & & & $\begin{array}{l}\text { Lower } \\
\text { Limit }\end{array}$ & $\begin{array}{l}\text { Upper } \\
\text { Limit }\end{array}$ & \\
\hline HIV/AIDS Status & $\leftarrow$ & $\begin{array}{l}\text { Sexual Behavior (single } \\
\text { sexual partner) }\end{array}$ & -4.47 & -6.65 & -2.30 & $<0.001$ \\
\hline \multirow{2}{*}{ Sexual Behavior } & $\leftarrow$ & Good Attitude & 1.26 & 0.02 & 2.50 & 0.045 \\
\hline & $\leftarrow$ & Good Family Support & 1.86 & 0.69 & 3.03 & 0.002 \\
\hline Attitude & $\leftarrow$ & Good Knowledge & 2.06 & 0.86 & 3.26 & 0.001 \\
\hline
\end{tabular}

\section{DISCUSSIONS}

1. The effect of knowledge on HIV/AIDS status in housewives

The result of this study showed that there was an effect of knowledge on HIV/AIDS status among housewives through attitude and sexual behavior which was statistically significant. Housewives often got counseling about HIV/AIDS including prevention methods, ways of transmission, treatment methods, and how to detect someone's HIV / AIDS status. Even though there were some people who did not join the counseling because they did not have time. However, the information was still delivered to the entire housewives from the people around them in everyday interaction. In addition, the housewives also received information from electronic media and the existence of posters about HIV/AIDS in health facilities, both government and private.

Knowledge as needed to answer and overcome some problems in daily life so that the knowledge would be useful for the basis of human behavior (Robbins, 2007).

Similar study was done in Malaysia by Wong (2008), it was stated that knowledge of the research subject on HIV/AIDS affec- 
Journal of Epidemiology and Public Health (2017), 2(2): 154-163

https://doi.org/10.26911/jepublichealth.2017.02.02.06

ted HIV/AIDS status. Another study conducted by Susilowati (2011) in Semarang, it was also stated that there was an effect of knowledge on HIV/AIDS cases. Based on the analysis conducted with Chi square, it was known that there was an effect of the knowledge level on the incidence of HIV and AIDS with OR 2,442, epidemiologically, people with low level of knowledge were 2,442 times more likely to get infected by HIV and AIDS. Another study was done in Sulawesi by Fadhali (2012), the result showed that the coefficient score of the effect of knowledge on HIV/AIDS was 0.361, it mean that knowledge contributed $36.1 \%$ to HIV and AIDS prevention. The research conducted by Ningsih (2015) showed the OR score by 2.31. It mean that FSW with high knowledge were 2.31 times more likely to conduct HIV/AIDS prevention compared to FSW who have lack of knowledge, and it was statistically significant. $(p=0.014)$.

\section{The effect of attitude on HIV/AIDS status in housewives}

The result of this study showed that Housewives' attitudes in sexual activity with their husbands mostly have good attitudes in the sense that most housewives already have good attitudes and views on their husbands when they intended to do sexual activity. Statistically, it also showed the effect of attitudes on the HIV/AIDS status of housewives. This attitude was the result of the benefit and loss consideration of the behavior (outcomes of the behavior). Besides that, it was also important to consider the individual consequences (evaluation regarding the outcome).

A study done by Fadhali (2012) showed similar result, the score of attitudes towards HIV and AIDS prevention from the study was $\mathrm{p}<0.001$, this also mean that there was a relationship between attitudes and the prevention of HIV/AIDS. Statistically, $\mathrm{b}=0.46$, which mean that the attitu- de contributed $46.4 \%$ to HIV/AIDS prevention.

\section{The effect of family support on HIV/AIDS status in housewives}

The result of this study showed that there was an effect of family support on HIV/AIDS status among housewives through sexual behavior which was statistically significant. They got some information about HIV/AIDS from the family in everyday interaction. The role of family members was highly important in dealing with health problems, a broad and comprehensive approach was needed because every individual stay with the family and community since she/he was born. Especially in family group because this group would influence each other (Prasetyawati, 2011).

The result of this study was in line with a study done by Budiono (2011). The study showed that the number of HIV/AIDS prevention consisted of $62.9 \%$. Factor which related to HIV/AIDS prevention was family support $(\mathrm{p}=0.032)$. Different study was conducted by Fadhali (2012). The results of the study with the chi-square test showed that there was no relationship between family support and HIV/AIDS prevention.

\section{The effect of sexual behavior on HIV/AIDS status in housewives}

The result of this study showed that there was an effect of sexual behavior on HIV/AIDS status among housewives. Primary data showed that Study Subjects with of multiple sexual partners have greater vulnerability than those who have single sexual partners.

The result of this study was in line with a study done by Dorjgochoo (2009) which stated that HIV infection at a young age was mostly occurred in Study Subjects who have sexual partners who have been infected by STD. This was in line with the data collected by UNAIDS (2003) which 
showed that the incidence of HIV/AIDS at a young age was mostly through heterosexual relationship.

Different study was conducted by Saleh (2012) which showed that there was no relationship between risky sexual behavior and HIV/AIDS status, with the results of the phi correlation test which showed that there was no relationship between risky sexual relations and HIV/AIDS status. However, from the results of the correlation coefficient of $\mathrm{C}$ contingency test, there was a relationship $(\mathrm{p}=0.040)$ between the existence of other sexual partners of the Study Subjects' partners and HIV status. The score of $\mathrm{C}=0.325$ indicated the strength of moderate correlation and cross tabulation showed that the subjects whose partners had no other sexual partners tended to not be infected by HIV.

\section{REFERENCE}

Dorjgochoo T, Noel F, Deschamps MM, Theodore H (2009). Risk factors for HIV infection among Haitian adolescents and young adults seeking counseling and testing in Port-au-Prince. J. Acquir. Immune. Defic. Syndr., 52(4): 498-508.

Ministry of Health (2011). Infodatin Situasi dan Analisis HIV AIDS. Jakarta

National AIDS Commission of Indonesia (2010). Strategi dan rencana aksi nasional penanggulangan HIV dan AIDS 2010-2014. Jakarta.

Kusrini (2009). Sistem Pakar, Teori, dan Aplikasi. Yogyakarta: ANDI. 2009

Prasetyawati AE (2011). Ilmu Kesehatan Masyarakat untuk kebidanan holistik (integrasi community oriented ke family oriented). Yogyakarta: Nuha Medika.

Spiritia (2009). Dasar AIDS. http://spiritia.or.id/art/pdf/a1001.pdf. Diakses tanggal o2 Februari 2017.

Spiritia (2016). Statistik Kaus HIV/AIDS di Indonesia. http://spiritia.or.id/Starts/star2016.pdf Diakses 25 Januari 2017.

Susilowati T (2011). Faktor -Faktor Risiko Yang Berpengaruh Terhadap Kejadian HIV Dan AID di Semarang Dan Sekitarnya. Purworejo: http://e-journal.akbidpurworejo.ac.id/index.php/jkk2 /article/view/45. Diakses tanggal 10 Februari 2017.

UNAIDS (2016). Global AIDS Update 2016. Global Report. UNAIDS

WHO (2013). UNAIDS and UNODC. Policy Brief: Reduction of HIV Transmission In Prions. Geneva:WHO.

WHO (2016). HIV/ AIDS. http://www.who.int/mediacentre/factsheets/fs36 o/en/. Diakses tanggal 6 November 2016. 